\title{
Dynamic Modeling of In-Use Cement Stocks in the United States
}

\author{
Amit Kapur, Gregory Keoleian, Alissa Kendall, \\ and Stephen E. Kesler
}

\section{Keywords:}

industrial ecology

infrastructure

lifetime distribution

material flow analysis (MFA)

probability of failure

substance flow analysis

:// Supplementary material is available on the JIE Web site

\author{
Address correspondence to: \\ Amit Kapur \\ PE Americas \\ 344 Boylston Street, 3rd Floor \\ Boston, MA 02116 \\ a.kapur@pe-international.com \\ http://www.pe-americas.com
}

(C) 2008 by Yale University

DOI: $10.1111 / \mathrm{j} .1530-9290.2008 .00055 . \mathrm{x}$

Volume 12, Number 4

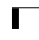

\section{Summary}

A dynamic substance-flow model is developed to characterize the stocks and flows of cement utilized during the 20th century in the United States, using the generic cement life cycle as a systems boundary. The motivation for estimating historical inventories of cement stocks and flows is to provide accurate estimates of contemporary cement in-use stocks in U.S. infrastructure and future discards to relevant stakeholders in U.S. infrastructure, such as the federal and state highway administrators, departments of transportation, public and private utilities, and the construction and cement industries. Such information will assist in planning future rehabilitation projects and better life cycle management of infrastructure systems. In the present policy environment of climate negotiations, estimates of in-use cement infrastructure can provide insights about to what extent built environment can act as a carbon sink over its lifetime. The rate of addition of new stock, its composition, and the repair of existing stock are key determinants of infrastructure sustainability. Based upon a probability of failure approach, a dynamic stock and flow model was developed utilizing three statistical lifetime distributionsWeibull, gamma, and lognormal_for each cement end-use. The model-derived estimate of the "in-use" cement stocks in the United States is in the range of 4.2 to 4.4 billion metric tons (gigatonnes, Gt). This indicates that $82 \%$ to $87 \%$ of cement utilized during the last century is still in use. On a per capita basis, this is equivalent to 14.3 to 15.0 tonnes of in-use cement stock per person. The in-use cement stock per capita has doubled over the last 50 years, although the rate of growth has slowed. 


\section{Sustainability Challenges for Concrete Infrastructure Systems}

Infrastructure plays a vital role in meeting the basic needs of society, including transportation, shelter, communications, and other essential services. The design and management of infrastructure systems greatly influence the quality of these services and have significant environmental, economic, and social costs and benefits. Infrastructure systems generally require large capital and resource investments to construct and maintain. Sustainability challenges facing infrastructure materials and systems are enormous and complex. The key attributes of sustainable infrastructure systems are as follows: improved performance, extended service life, optimal life-cycle costs, and minimal environmental life-cycle impacts, including minimizing the use of virgin raw materials (Horvath 2004). The rate of addition of new stock, its composition in terms of material use and service life, ${ }^{1}$ and the repair of existing stock are key determinants of infrastructure sustainability.

Some of the key indicators that demonstrate the sustainability challenge of infrastructure systems in United States are as follows.

\section{Environmental}

- Crushed stone and construction sand and gravel accounted for $75 \%$ of the 3,400 million metric tons (megatonnes, $\mathrm{Mt})^{2}$ of new materials entering the U.S. economy in the year 2000 (Wagner 2002). Approximately $70 \%$ of crushed stone production in the United States is limestone, one of the basic raw materials required for cement production (USGS 2003). Cement, construction sand, and gravel are essential ingredients of concrete.

- Cement production consumes a significant amount of fossil fuels. Although the energy intensity of 5.1 megajoule/kilogram $(\mathrm{MJ} / \mathrm{kg})^{3}$ is relatively low compared to steel and aluminum, the large volume of production influences overall energy use (van Oss and Padovani 2002).
- In the United States, cement accounts for $3.4 \%$ of total carbon dioxide emissions from all sources, excluding motor vehicles and power plants (van Oss and Padovani 2003).

- Approximately $136 \mathrm{Mt}$ of construction and demolition debris were generated in the United States in the year 1996, equivalent to $1.3 \mathrm{~kg}$ per person per day (USEPA 1998).

\section{Socioeconomic}

- As of 2001, an estimated one third of the U.S. major roadways were in poor or mediocre condition (ASCE 2001). Similarly, $27.1 \%$ of bridges were structurally deficient or functionally obsolete in 2003 (ASCE 2005).

- The cost of improving and maintaining highways and bridges in United States over the 2001-2020 period is projected to be about $\$ 184$ billion (in 2000 dollars; US. DOT 2002).

- In the year 2000, an average peak-period trip under congested conditions required $50 \%$ more time compared with the same trip under nonpeak and noncongested conditions (USDOT 2002).

- In the year 2002, congestion caused a total delay of 3.5 billion hours, at a cost of about $\$ 66$ billion (in constant 2000 dollars) in the United States (Schrank and Lomax 2004).

Globally, contemporary concrete production has increased rapidly, and, as of the early part of the first decade of this century, was approximately 12-15 billion tonnes (gigatonnes, Gt) per year (van Oss and Padovani 2002); for the United States, it has been in the range of 800 to $1,000 \mathrm{Mt} /$ year (van Oss 2006). Concrete usually consists of $11 \%$ to $14 \%$ cement on a weight basis. Concrete is the most widely used manufactured construction material for buildings, bridges, streets, and highways. The management of concrete stock in the form of buildings, roads, bridges, and so forth built up over the 20th century can influence the flows of material and energy resources. There are growing concerns about the condition and performance of, especially, the concrete infrastructure in the United States, and it is estimated that $\$ 1.6$ trillion of investment will be 
required by 2010 to replace and/or rehabilitate existing infrastructure (ASCE 2005). The various categories of infrastructure in the United States scored an overall grade of D (i.e., poor) in an assessment by the American Society of Civil Engineers in 2005 (ASCE 2005). The grade was based on the condition and performance of each infrastructure category and the shortfall in capacity and funding that is influencing performance as well. There can be critical environmental and economic implications when the infrastructure systems perform badly. Deteriorating infrastructure drives demand for new and better concrete infrastructure, and, as a result, there is increased demand for cement, leading to environmental impacts of extraction of virgin resources and increased fossil-fuel-based energy use. Users of transportation infrastructure face delays and long detours, which lead to increased energy use by and emissions from automobiles.

The objective of this study is to characterize the stocks and flows of cement (as a proxy for concrete) utilized during the 20th century in the United States. The information on in-use cement stocks and their age distribution is pertinent and important for stakeholders in U.S. infrastructure (e.g., federal and state highway administrators, departments of transportation, public and private utilities, and the construction and cement industries) to plan and implement appropriate measures for life cycle management of infrastructure.

\section{Industrial Ecology Perspective for Analysis}

The extraction, production, use, and end-oflife management of resources can have significant environmental implications for natural ecosystems. The approach to establish and quantify the relationship between societal resource management and sustainability is an emerging subject of research in the field of industrial ecology (IE; Graedel and Klee 2002). Industrial ecologists using analytical tools such as material flow analysis (MFA) and substance flow analysis (SFA) have determined the anthropogenic contribution to natural material flows of various resources, such as copper, zinc, lead, paper, plastics, and wood (Baccini and Brunner 1991; Palm and Ostlund 1996;
Patel et al. 1998; Guinée et al. 1999; Hekkert et al. 2000; Joosten et al. 2000; Kleijn et al. 2000; Michaelis and Jackson 2000a; Michaelis and Jackson 2000b; Spatari et al. 2002; Graedel et al. 2002; Graedel et al. 2004; Graedel et al. 2005; Elshkaki et al. 2005; Spatari et al. 2005).

Most of the material flow studies provide a static snapshot, either over a 1-year time period or averaged over a few years, of the systems under consideration. Such static material cycles do not depict the temporal dynamics of stock and flow characteristics. The use of dynamic models helps to evaluate the accumulation of the stock of materials, either in use or deposited in waste repositories, such as landfills. Although previous material flow studies have examined the flows of construction materials, including cement (Kelly 1998), no studies have comprehensively characterized the accumulation of cement in-use stock in the form of buildings (residential, commercial, and public buildings) and civil infrastructure (airports, roads, highways, bridges, railway and power infrastructure, water supply distribution, and waste-water collection). Most of the earlier dynamic SFA studies that have estimated the stock of construction materials in the built environment have primarily focused on estimating building and housing stocks using a single lifetime distribution for residential buildings (Bratteb $\varnothing$ et al. 2005; Müller 2006). A lifetime distribution for a building or an infrastructure system depicts the time span over which the building is expected to deliver the desired level of performance. Müller (2006) incorporates socioeconomic variables as well, such as useful floor area per dwelling and population, along with variations in material composition (concrete use per unit area) to illustrate concrete construction inflows and concrete demolition outflows. Although the approach of Müller (2006) to integrate dynamic modeling with socioeconomic variables is useful to assess stocks of residential buildings, it cannot be applied to comprehensively assess the total stock of a civil infrastructure system for a country. This is because a particular infrastructure, such as a bridge, will provide service to fewer people in a rural area as compared to infrastructure in an urban or semiurban area.

In this study, we have estimated the stock accumulation of in-use cement in buildings, roads, 


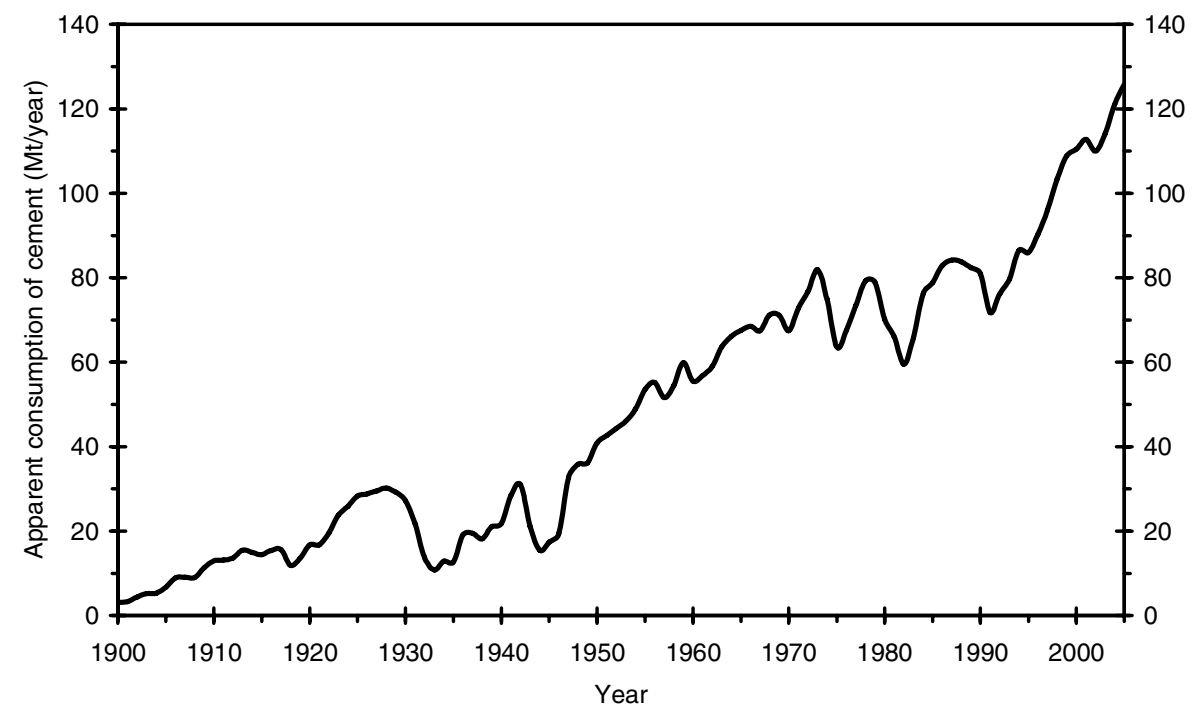

Figure I Consumption of cement in the United States. Data source: van Oss and Kelly (2005).

highways, and bridges, as well as cement discards in landfills in the United States over the period 1900-2005 using different lifetime distributions. The objective of using different lifetime distributions (Weibull, lognormal, and gamma) is to characterize the sensitivity of results to a wide spectrum of life spans of civil infrastructure systems consisting of both short-lifetime structures (roads and highways) and long-lifetime structures (buildings and bridges). The input flow and lifetime distribution are the two variables that can influence the results in a dynamic SFA model (Zeltner et al. 1999; Kleijn et al. 2000; Spatari et al. 2005). Previous work by Bratteb $\varnothing$ and colleagues (2005) and Müller (2006) and other dynamic SFA models developed to assess stocks of polyvinyl chloride (Kleijn et al. 2000), copper (Spatari et al. 2005), and lead (Elshkaki et al. 2005) have also used a single lifetime distribution (normal or Weibull) in their analysis. Because there is a lack of empirical data on lifetime distribution of products and infrastructure systems, this study proposes a probability of failure approach to more accurately characterize lifetime distribution. By definition, probability of failure is the probability that a particular infrastructure or product will fail-that is, it cannot deliver the desired performance and has to be taken out of service (Nowak and Collins 2000).
The integration of a probabilistic approach with dynamic modeling represents a significant advancement in methodology because it attempts to capture the stochastic nature of failure of infrastructure systems with a more robust and scientific approach. A dynamic substance-flow model is developed from time-series annual data on cement consumption and lifetime distributions for each cement end-use infrastructure application. The lifetime distribution determines the residence time of the in-use stock in the "use" reservoir.

The consumption of cement in the United States has increased sixfold over the last 50 years (figure 1). Over the 20th century, the total cement consumption in the United States was approximately 5 Gt. Apparent cement consumption ${ }^{4}$ was partitioned into various end-use markets, such as roads, bridges, highways, buildings (residential, commercial, and public), and water and waste-water utilities, on the basis of historical and contemporary data available from the U.S. Geological Survey (USGS). The contemporary cement end-use market in the United States for the year 2003 is shown in figure 2 .

\section{The Life Cycle of Cement}

The material life cycle of cement consists of three life stages: production (including raw 


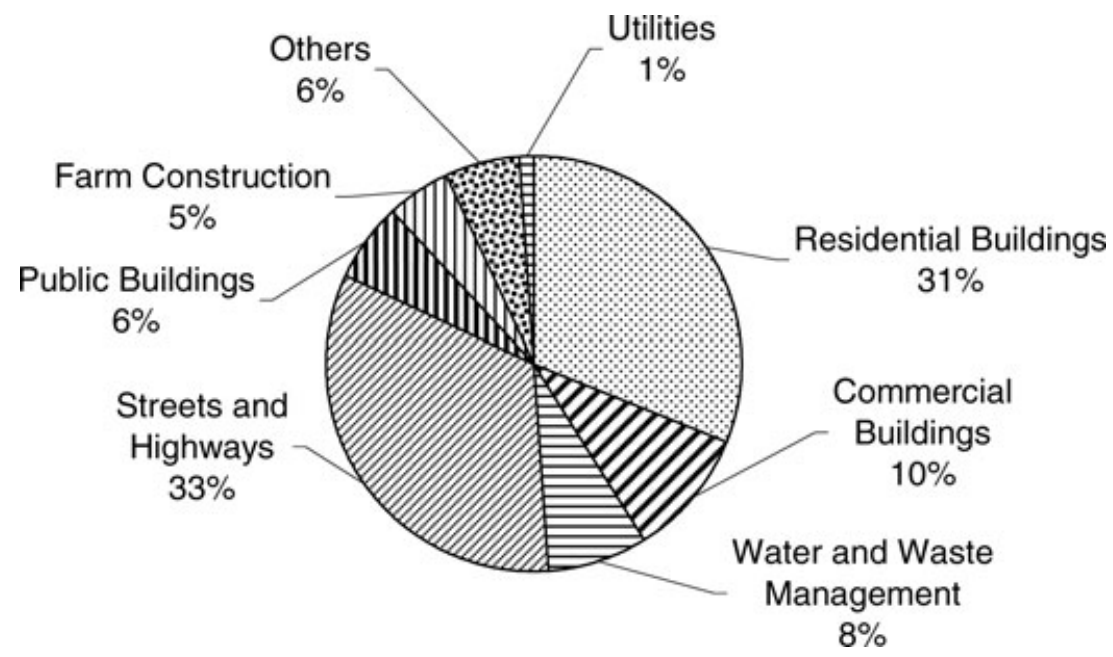

Figure 2 Cement end-use market in the United States, 2003. Data source: Portland Cement Association (2005).

material extraction), use, and end of life (waste management). A diagram showing a generic cement life cycle (figure S1) is provided in an appendix available as Supplementary Material on the Web. ${ }^{5}$ At each life-cycle stage there can be material exchanges with other reservoirs, including the lithosphere, environment, and material imports and exports. The production of a particular type of cement depends on the physical and chemical specifications it is required to meet, as per various codes and standards based on the intended structural use. The raw materials required for the manufacture of cement are usually a combination of calcareous (limestone, cement rock, coral, and marble), aluminous (clay and shale), siliceous (sand and sandstone), ferrous (iron ore and millscale), and other miscellaneous rock and industrial materials (gypsum, anhydrite, slags, fly ash, and other types of ash; van Oss and Padovani 2002). To minimize costs, cement plants are generally located very close to their limestone quarries. At the quarry, the raw materials are crushed to smaller size particles and then transported to the cement plant, where they are ground and blended with other materials. The blended mix is pyroprocessed in a kiln to produce clinker, which is ground with gypsum in the finishing mill to produce cement. The contemporary nonfuel raw materials consumption for the manufacture of cement and clinker in the United States is given in table S1 in the appendix on the Web. It takes about $1.64 \mathrm{Gt}$ of raw materials to produce $1 \mathrm{Gt}$ of cement (van Oss and Padovani 2002). A more detailed description of cement manufacture is given by Alsop and colleagues (2005), Duda (1995), and van Oss and Padovani (2002).

\section{Methodology}

The law of conservation of mass is the basic principle on which a stocks and flows model is constructed. The underlying equation can be expressed as

$$
\frac{\mathrm{d} F}{\mathrm{~d} t}=\sum F_{\mathrm{i}}-\sum F_{\mathrm{o}}=\Delta_{\text {stock }}
$$

where $F_{\mathrm{i}}$ and $F_{\mathrm{o}}$ are material inputs and outputs of the reservoir under consideration within the system boundary of the material cycle. The balance between inputs and outputs, or lack thereof, can lead to the following three conditions for change in stock $\left(\Delta_{\text {stock }}\right)$ :

$\sum F_{\mathrm{i}}>\sum F_{\mathrm{o}} \quad$ (Build up of material stock)

$\sum F_{\mathrm{i}}<\sum F_{\mathrm{o}} \quad$ (Decline of material stock)

$\sum F_{\mathrm{i}}=\sum F_{\mathrm{o}} \quad$ (No change in material

stock/Steady state) 
In the present technological society, there is net accumulation of material stock in the use reservoir, as material inflows exceed the material outflows.

The outflow of cement discard streams depends on the time delay between the input and output flows of cement-that is, the lifespan or lifetime of the cement. The residence time of the product determines the time delay. The residence-time distribution (lifespan distribution) of the product is usually assumed to be a Weibull, gamma, or lognormal distribution (Melo 1999; OECD 2001; Elshkaki et al. 2005). Given a particular lifetime distribution, the rate of cement discards exiting the use reservoir can be determined via the following equation:

$$
F_{i, j}^{W}=\sum_{i=1}^{8} \sum_{j=1900}^{2000} \sum_{k=0}^{j-1900} F_{i, j-k}^{U} \times d_{i, k}
$$

where

$$
\begin{aligned}
F_{i, j}^{W}= & \text { cement discard flow from sector } i \text { in } \\
& \text { the year } j ; \\
F_{i, j-k}^{U}= & \text { cement flow into sector } i \text { in the year } \\
& j-k ; \\
i= & \text { sector category index, varying from } \\
& 1 \text { to } 8 \text { for sectors including streets and } \\
& \text { highways, residential buildings, com- } \\
& \text { mercial buildings, public buildings, wa- } \\
& \text { ter and waste management, utilities, } \\
& \text { farm construction, and other uses } \\
j= & \text { year of cement discard, } 1900<j<2000 \\
k= & \text { index for invoking the lifetime distrib- } \\
& \text { ution function to estimate the retire- } \\
& \text { ments of in-use cement from sector } i \\
& \text { that entered use in years represented } \\
& \text { by } k, 0 \leq k \leq j-1900 \\
d_{i, k}= & \text { lifetime distribution density value. } \\
& \text { The probability density function for } \\
& \text { the different lifetime distributions is } \\
& \text { given in the appendix, available as } \\
& \text { Supplementary Material on the Web }
\end{aligned}
$$

There is a lack of literature and/or data that quantify actual lifetime distributions of various infrastructure applications. The lifetime distribution can be determined mathematically if data are available on the age distributions ${ }^{6}$ of infrastructure in use and demolished (van Noortwijk and Klatter 2004). Using this approach, van
Noortwijk and Klatter (2004) and Komastu and colleagues (1992) determined the in-use stock of bridges in the Netherlands and of residential buildings in Tokyo, respectively. For the United States, data exist on age distribution of in-use bridges (ca. 2004) and housing units (ca. 2003) as shown in figures S2 and S3 in the Supplementary Material on the Web. There are no data, however, on the age distribution of demolished infrastructure, except for number of housing units demolished over the last several decades (JCHS 2001). The Bureau of Economic Analysis in the United States, in its assessment of the stocks and depreciation of fixed assets and consumer durables, does, however, report mean service life values of different types of infrastructure (BEA 2003). The mean service life data are derived from a variety of sources, such as industry reports, government surveys, and research studies.

In the absence of data to quantify lifetime distributions, a probability of failure approach was adopted to estimate the parameters required to mathematically define a lifetime distribution. Each of the lifetime distributions-Weibull, gamma, and lognormal — is defined by two parameters. Therefore, a range of values was assumed for the 50th and 90th percentile for the cumulative probability distribution function (CDF; table 1). An expert opinion survey was carried out to seek the range of CDF values for the 50th and 90th percentile for each infrastructure use. The 50th percentile value was centered around the mean service life value. A range of values was selected, rather than discrete values, to include the plausible uncertainties in the lifetime data.

The parameters for each lifetime distribution for each infrastructure end-use category are shown in table 1 . The parameters were derived via Monte Carlo simulations over the range of 50th and 90th percentile CDF values. The lifetime distributions for residential buildings and streets and highways are characterized in figures 3 and 4 , respectively. A Weibull distribution widens the "time spread" of cement discards. A gamma distribution tends to have a longer tail as compared to the other two distributions. The lognormal distribution is more time constricted.

The cement end-use sectors were not further categorized (e.g., streets and highways into state highways, urban streets and roadways, rural 
Table I Estimation of parameters of the lifetime distributions

\begin{tabular}{|c|c|c|c|c|c|c|}
\hline $\begin{array}{l}\text { End-use } \\
\text { category }\end{array}$ & $\begin{array}{l}\text { Mean service } \\
\text { life }^{a} \text { (years) }\end{array}$ & $\begin{array}{l}\text { Range for 50th } \\
\text { percentile of } \\
\text { cumulative } \\
\text { probability } \\
\text { of failure }\end{array}$ & $\begin{array}{l}\text { Range for 90th } \\
\text { percentile of } \\
\text { cumulative } \\
\text { probability } \\
\text { of failure }^{b}\end{array}$ & $\begin{array}{c}\text { Weibull } \\
\text { parameters }\end{array}$ & $\begin{array}{c}\text { Gamma } \\
\text { distribution } \\
\text { parameters }\end{array}$ & $\begin{array}{l}\text { Lognormal } \\
\text { distribution } \\
\text { parameters }\end{array}$ \\
\hline Residential buildings & 80 & $70-90$ & $90-100$ & $85.8,5.5$ & $32.9,2.7$ & $4.38,0.16$ \\
\hline Commercial buildings & 70 & $60-80$ & $80-100$ & $75.1,4.8$ & $26.2,3.0$ & $4.24,0.2$ \\
\hline Public buildings & 90 & $80-100$ & $100-120$ & $95.6,6.1$ & $40.7,2.4$ & $4.53,0.11$ \\
\hline Utilities & 75 & $70-80$ & 80-90 & $78.0,9.9$ & $106.6,0.8$ & $4.32,0.10$ \\
\hline $\begin{array}{l}\text { Streets and } \\
\text { highways }\end{array}$ & 45 & $40-50$ & $50-60$ & $63.2,1.5$ & $41.4,1.2$ & $3.8,0.13$ \\
\hline $\begin{array}{c}\text { Water and waste } \\
\text { management }\end{array}$ & 60 & $50-70$ & $70-90$ & $65.6,4.2$ & $19.3,3.5$ & $4.14,0.16$ \\
\hline Farm & 70 & $65-75$ & $75-85$ & $72.9,9.2$ & $94.4,0.8$ & $4.3,0.08$ \\
\hline Other ${ }^{\mathrm{c}}$ & 60 & $55-65$ & $65-75$ & $62.9,8.0$ & $69.9,0.9$ & $4.1,0.11$ \\
\hline
\end{tabular}

a Derived from BEA (2003). ${ }^{b}$ Informed estimate. ${ }^{c}$ Includes parks, stadiums, and athletic fields; airport runways, taxiways, and lighting; defense and space facilities; railroads, tunnels, and signal systems; oil and gas wells; and mining and quarrying.

roadways, vehicle and pedestrian bridges, and maintenance and repair) due to lack of historical data. For the time periods for which cement enduse market share data were not available, missing values were interpolated on the basis of existing trends.

The in-use cement stock was estimated as the difference between cement entering the use

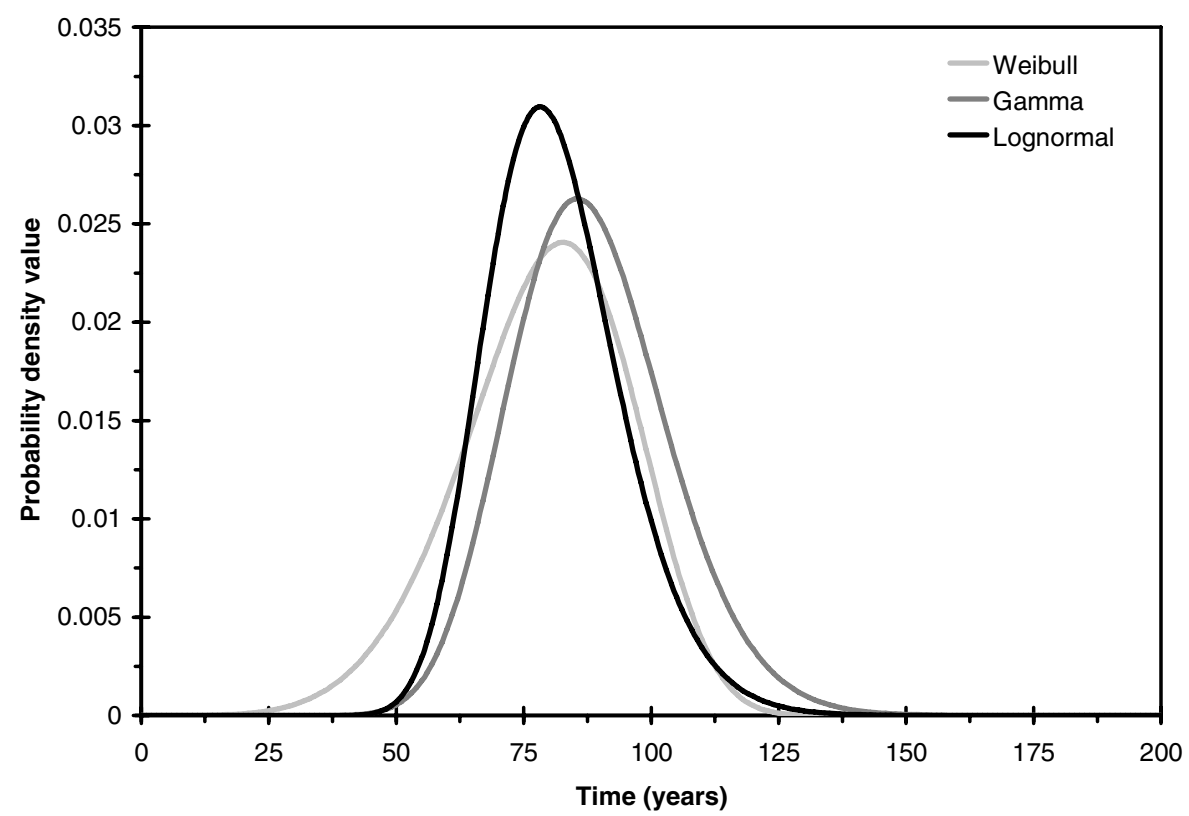

Figure 3 Lifetime distributions for residential buildings, derived via Monte Carlo simulations under the assumption that the 50th percentile of probability of failure lies in the range of 70-90 years and the 90th percentile of probability of failure lies in the range of 90-1 10 years. 


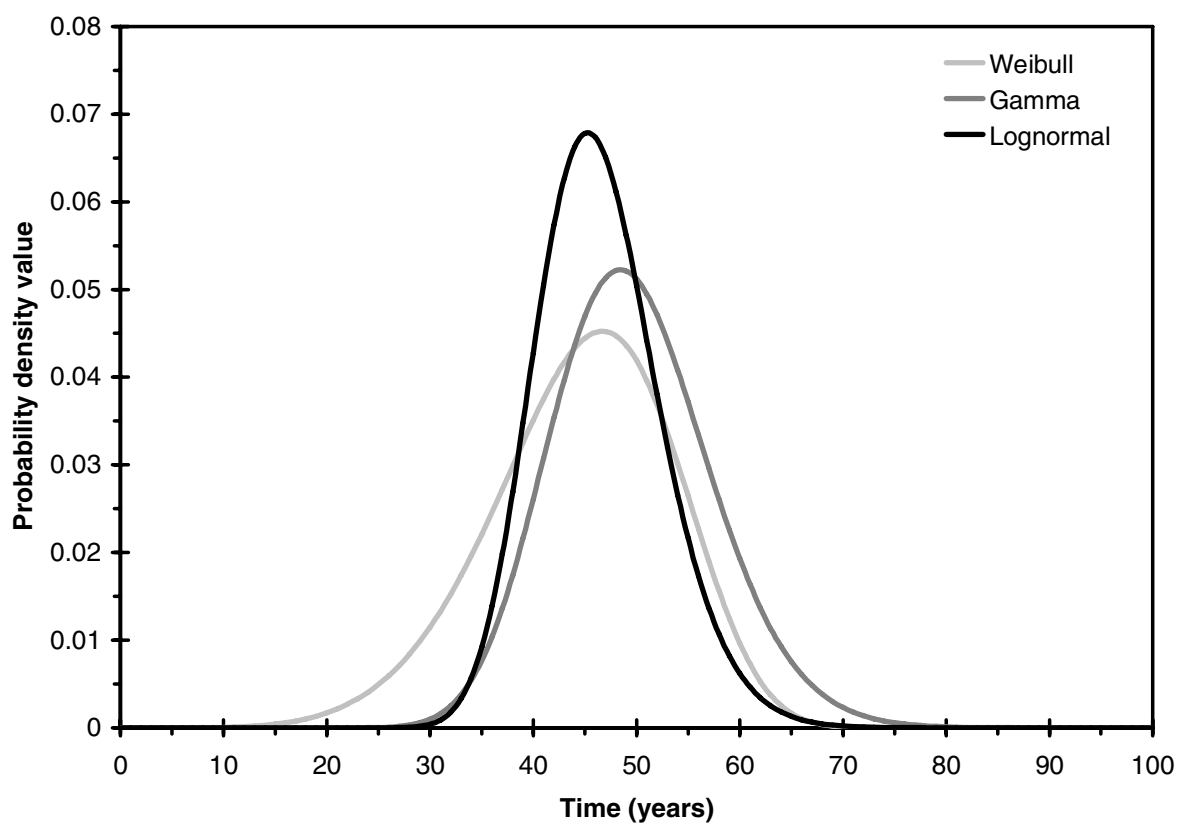

Figure 4 Lifetime distributions for streets and highways, derived via Monte Carlo simulations under the assumption that the 50th percentile of probability of failure lies in the range of 40-50 years and the 90th percentile of probability of failure lies in the range of 50-60 years.

reservoir and cement discards exiting the same reservoir. There is a lack of data on the extent of recycling ${ }^{7}$ of cement discards (van Oss, 2006; William Turley; Gwen Dipietrio; Melinda Tomaino Flores; Jason Harrington 2004; USEPA 1998). The USGS reports that $9.5 \mathrm{Mt}$ of cement concrete were recycled in the United States in the year 2000 (Bolen 2001; Tepordei 2001). The Associated General Contractors of America (AGC) conducted a survey in the year 2004 of approximately 300 contractors on their recycling

Table 2 Concrete recycling rates of construction and demolition projects in the United States, 2004

\begin{tabular}{lc} 
Type of project & $\begin{array}{c}\text { Concrete recycling } \\
\text { rate (\%) }\end{array}$ \\
\hline Building construction & $67-100$ \\
Highway construction & $33-100$ \\
Utility construction & $50-100$ \\
Demolition work & $57-100$ \\
\hline
\end{tabular}

Data source: Melinda Tomaino Flores, Associated General Contractors of America. practices for on-site construction and demolition debris. The results of the survey for concrete recycling are illustrated in table 2. Depending on the type of the project, the concrete recycling rates vary from $35 \%$ to $100 \%$. On the basis of AGC's survey and an expert opinion survey conducted as part of this study, a recycling rate of $60 \%$ was used in the dynamic model. The remaining $40 \%$ of cement discards was assumed to be landfilled. The recycling and landfilling rates were assumed to be constant over the time scale of the model. The choice of a lower or higher recycling rate would only influence the relative partitioning of the estimated total discards into the landfill and recycling reservoirs and does not affect the estimates of in-use stock.

\section{Results and Discussion}

The results of using different lifetime distributions to estimate net addition of in-use cement stock are shown in figure 5. The model-derived estimate of the in-use cement stocks in the United States is in the range of 4.2 to $4.4 \mathrm{Gt}$ for the year 


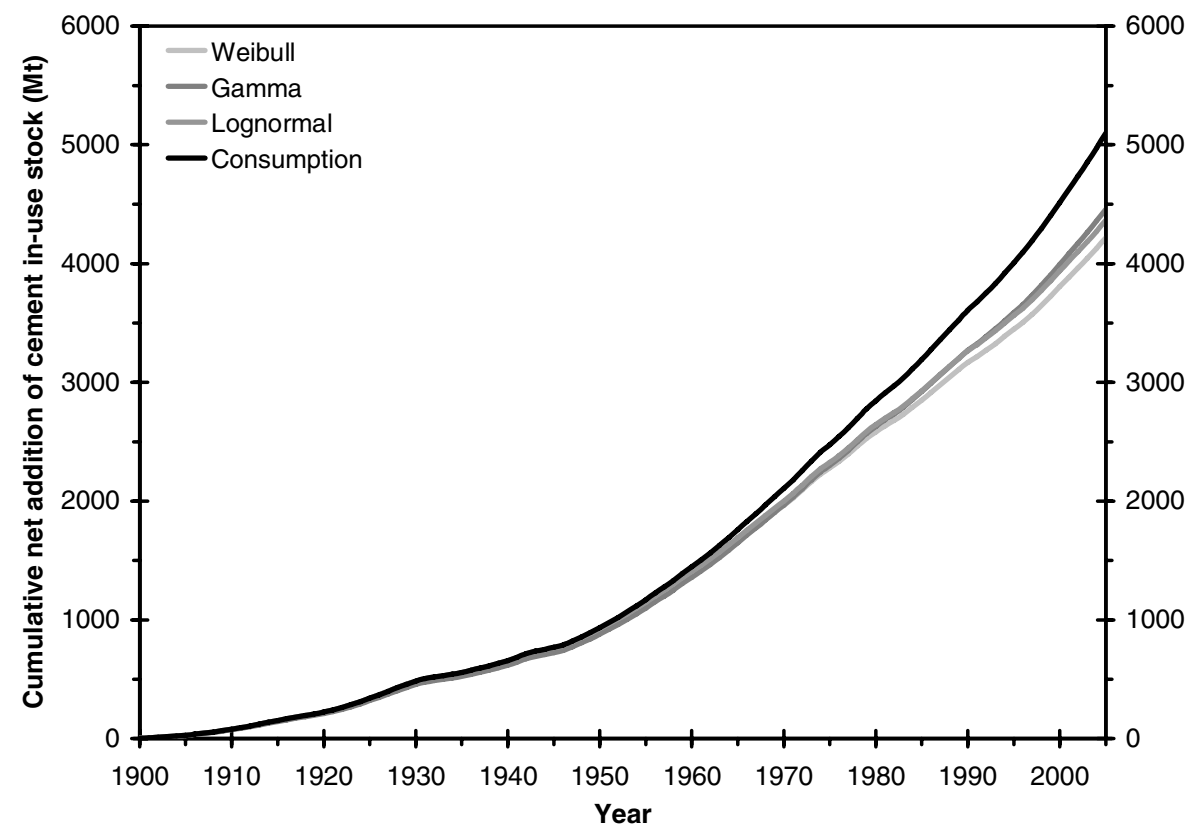

Figure 5 Cumulative net addition of cement in-use stock in the United States, 1900-2005.

2005, as shown in figure 5 . This indicates that $82 \%$ to $87 \%$ of the cement utilized during the last century is still in use. On a per capita basis, this is equivalent to 14.3 to 15.0 tonnes of in-use cement stock per person. In the United States, the cement footprint is represented by 8 million roadway-lane miles and 116 million housing units (BTS 2005; USCB 2005a). Figure 6

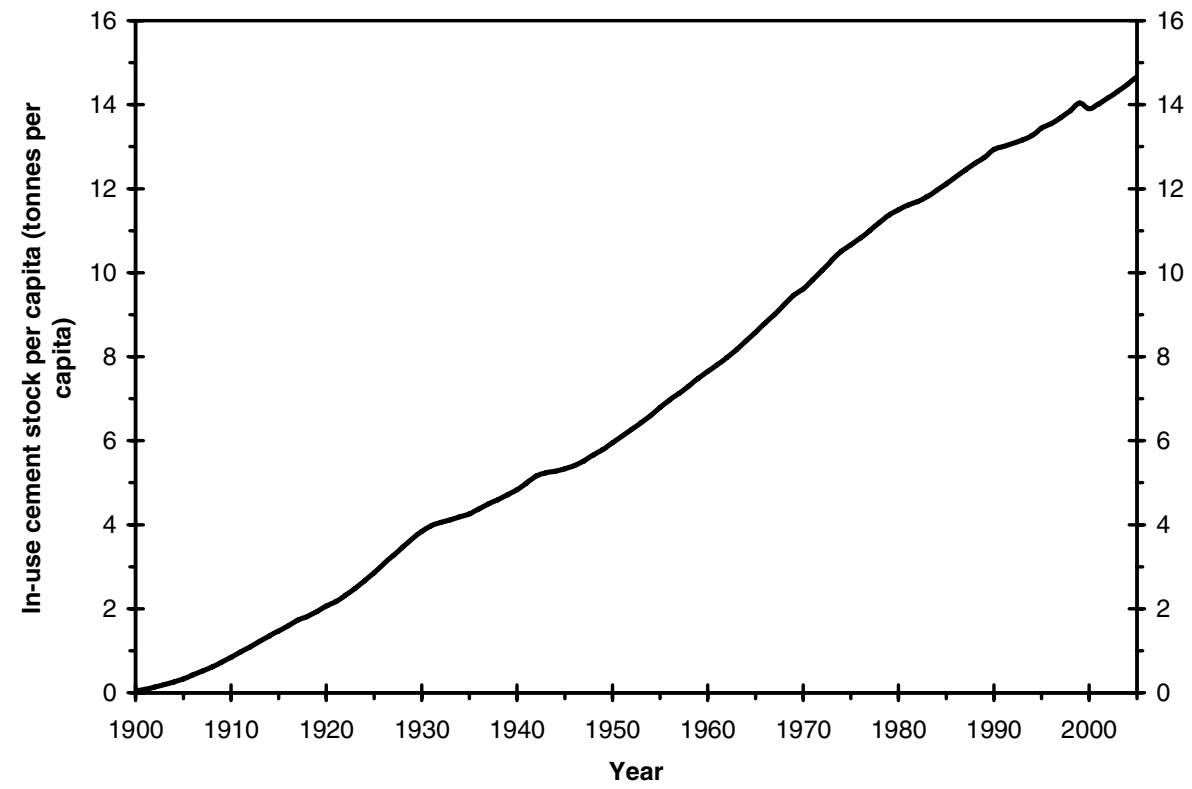

Figure 6 Growth of in-use cement stock per capita in the United States, 1900-2005. 
Table 3 Growth of in-use cement stock in the United States, 1900-2000

\begin{tabular}{ccccccc}
\hline Year & $\begin{array}{c}\text { Population }^{a} \\
\text { (million) }^{a}\end{array}$ & $\begin{array}{c}\text { Population } \\
\text { growth }^{b}(\%)\end{array}$ & $\begin{array}{c}\text { In-use cement } \\
\text { stock per capita } \\
\text { stock }\end{array}$ (Gt) & $\begin{array}{c}\text { (tonnes } \\
\text { per capita) }\end{array}$ & $\begin{array}{c}\text { Insement } \\
\text { stock } \\
\text { growth (\%) }\end{array}$ & $\begin{array}{c}\text { In-use cement stock } \\
\text { per capita } \\
\text { growth (\%) }\end{array}$ \\
\hline 1900 & 76.1 & - & 0.003 & 0.04 & - & - \\
1925 & 115.8 & 1.7 & 0.3 & 2.9 & 20.2 & 18.8 \\
1950 & 152.3 & 1.1 & 0.9 & 6.0 & 4.5 & 3.0 \\
1975 & 216.0 & 1.4 & 2.3 & 10.7 & 3.8 & 2.3 \\
2000 & 282.2 & 1.1 & 3.9 & 13.9 & 2.1 & 1.1 \\
\hline
\end{tabular}

${ }^{\mathrm{a} U S C B} 2005 \mathrm{~b} .{ }^{\mathrm{b}}$ Average growth rate over 25 years. ${ }^{\mathrm{c}}$ Median value.

illustrates the growth of in-use cement stock per capita in the United States over the last century as derived from the models. The in-use cement stock per capita has doubled, and in-use cement stock has quadrupled, over the last 50 years. The growth of in-use cement stock is slowing, however, as shown in table 3 . The in-use cement stock is presently growing at a rate twice that of population growth in the United States. In the future, it is anticipated that the in-use stock of cement will grow at a rate at least equal to the population growth rate, given the increased demand for housing and expansion of civil infrastructure. The growth rate of in-use cement stock has remained fairly steady in the range of $2 \%$ to $3 \%$ over the last few decades and follows a similar pattern to the growth of cement consumption over the same time period. For the period 1900-2005, the range of model-derived cement discards that were recycled is 0.42 to $0.54 \mathrm{Gt}$, and the range for discards that were landfilled is 0.28 to $0.36 \mathrm{Gt}$, given an assumed recycling rate of $60 \%$.

The U.S. Environmental Protection Agency in a 1996 study estimated that the amount of construction and demolition debris generated from residential and nonresidential (excluding highways, roads, and bridges) sectors was approximately 6 Mt (USEPA 1998). For the year 1996, the stock model estimates for cement discards range from 26 to $29 \mathrm{Mt}$. This suggests that cement discards from bridges, highways, and roads are higher than discards from buildings. To investigate this further, we disaggregated the dynamic stock model into submodels for each end-use cat- egory to determine accumulation of cement discards by category of end use. We did this by assigning cement use in each end-use category as nil except for the end-use category under consideration. The range of cumulative cement discards by end-use category is shown in figure 7. Streets and highways account for the largest proportion of cement discards, followed by commercial buildings. The cement discards from public buildings are comparatively lower than from commercial buildings because of their longer lifetime. The lower and upper bounds of cement discards in the year 2005 for streets and highways and for residential buildings by the year the cement was put in service are shown in figures 8 and 9, respectively. For streets and highways, the maximum amount of cement discards is from the streets and highways built during 1945-1975, whereas for residential buildings it is over the 1910-1945 time period. This implies that there are older homes that still exist today, as compared to older streets and highways that have undergone several cycles of reconstruction. The age distribution of in-use cement stock in streets and highways and in residential buildings is shown in figures 10 and 11, respectively. The amount of in-use cement stock in streets and highways older than 30 years ranges between $21 \%$ and $31 \%$ of the total stock. The in-use cement stock in streets and highways older than 30 years is expected to require reconstruction over the next 10-15 years. It is difficult to correlate the age distribution of housing units in figure 11 and in-use cement stock in residential buildings in figure 9 because there are no empirical data on how the material composition of 


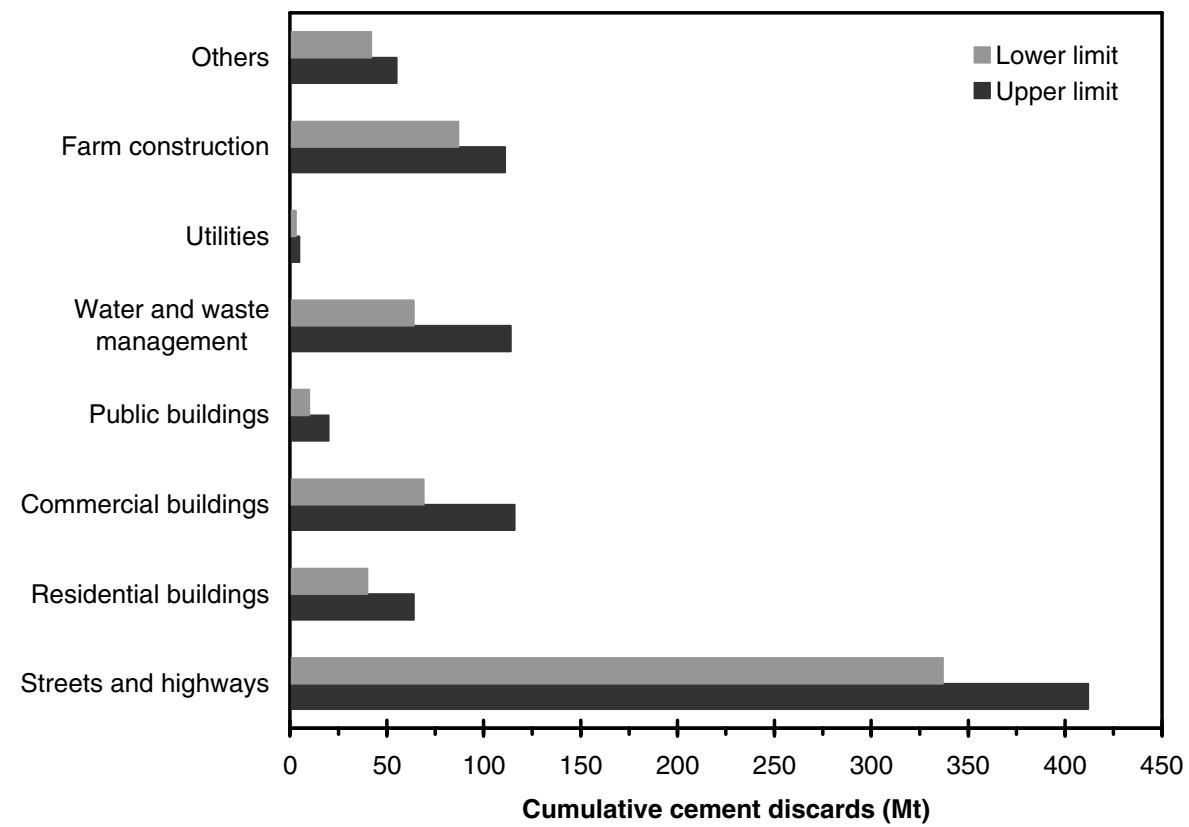

Figure 7 Range of cumulative cement discards by end-use category, 1900-2005.

housing units has changed over the last century in the United States.

The use of lifetime distributions usually dampens the "noise" in an analysis of historical time- series data because there is significant time delay between inflows and outflows. Figure 12 illustrates how cement consumption trends from 1964-2005 compare to value of construction and

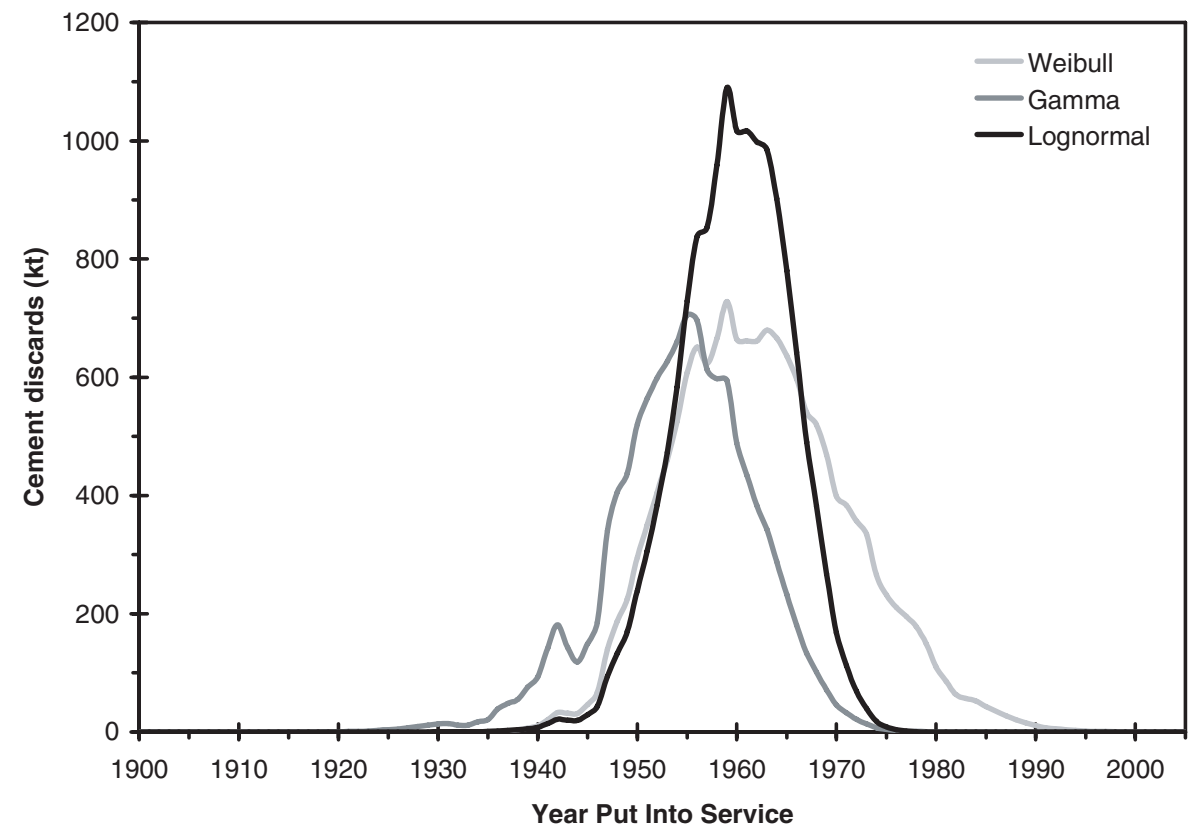

Figure 8 Cement discards from streets and highways in the year 2005 by the year put in service. 


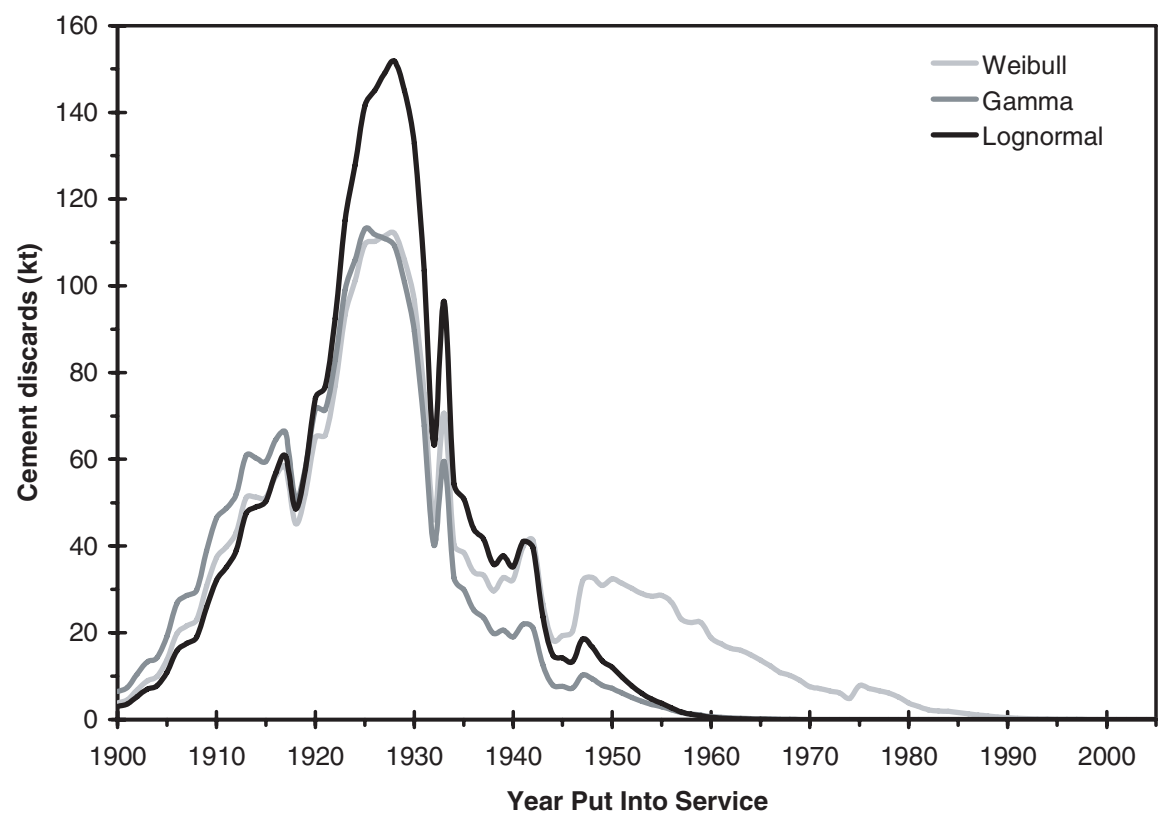

Figure 9 Cement discards from residential buildings in the year 2005 by the year put in service.

gross domestic product patterns (in constant 2000 U.S. dollars). The cement consumption is more strongly correlated to the value of construction $\left(R^{2}=0.930\right)$ than to gross domestic product
$\left(R^{2}=0.822\right)$. If the scale on the ordinate axis in Figure 12 is changed to a finer scale, it is observed that cement consumption follows a cyclical pattern similar to value of construction in the United

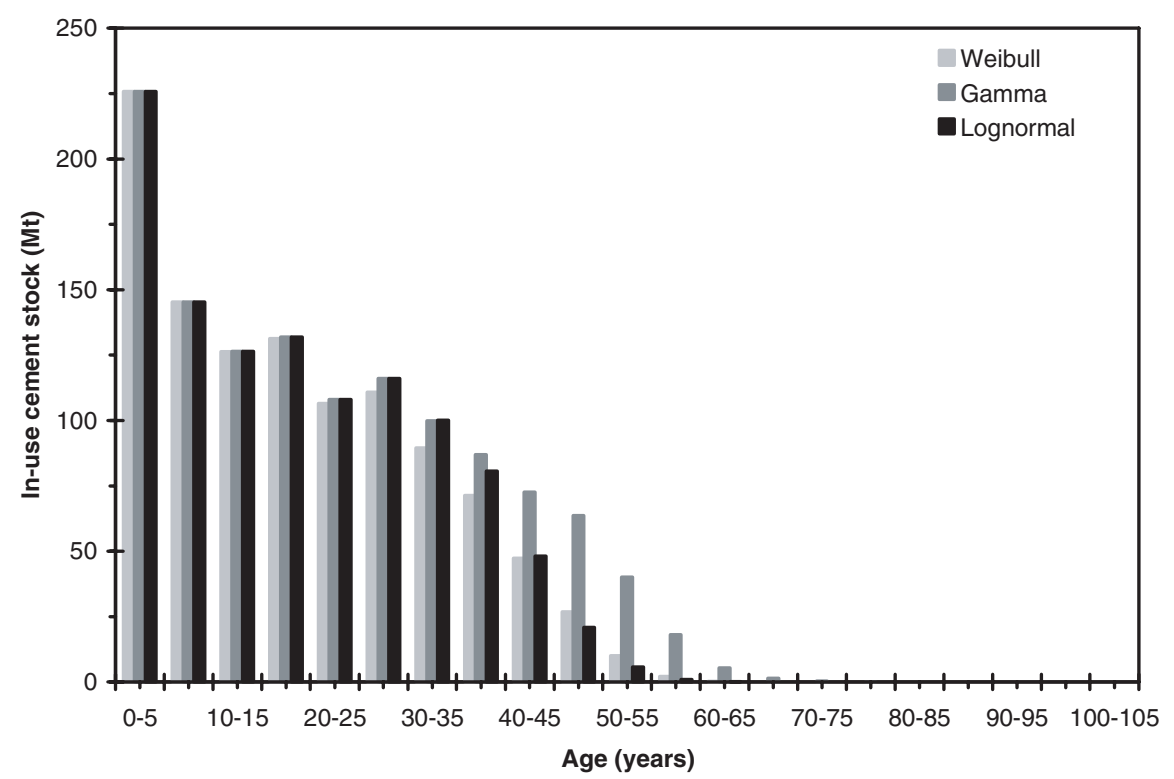

Figure 10 Age distribution of model-derived in-use cement stock in streets and highways in the United States. 


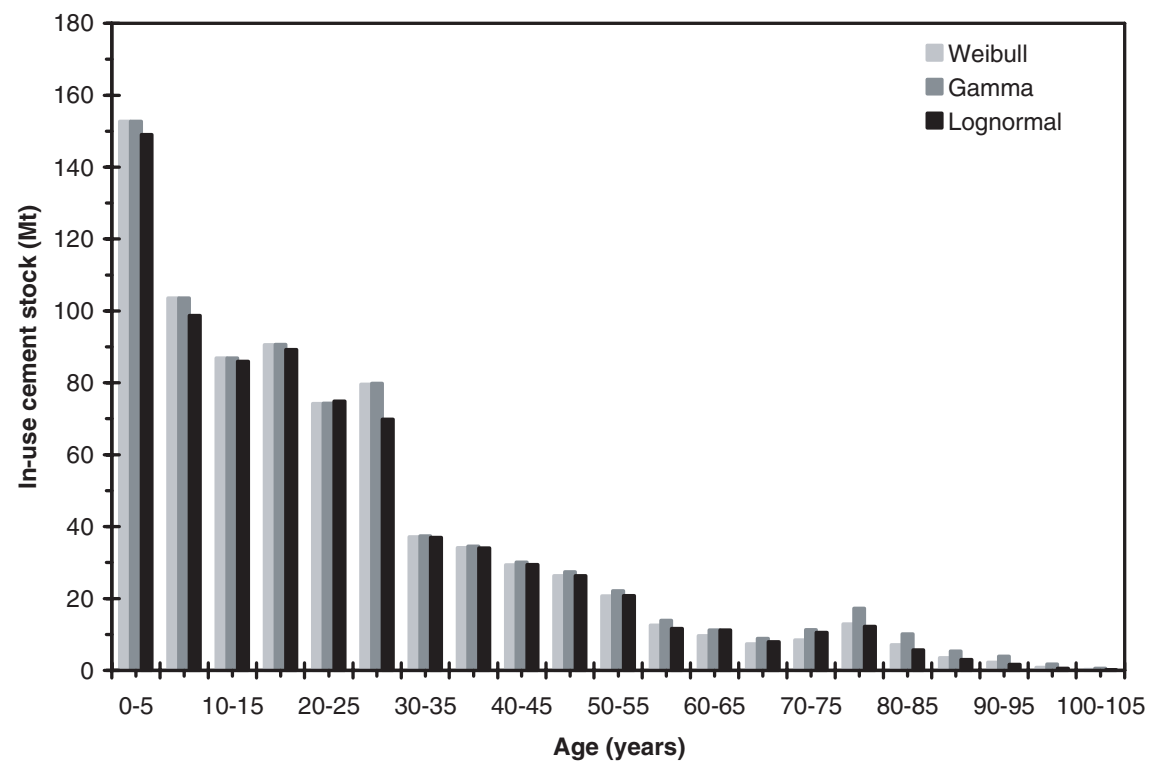

Figure II Age distribution of model-derived in-use cement stock in residential buildings in the United States.

States. Patterns of cement discards estimated by the stock model indicate a smoother and flatter trend, however. Thus, it is difficult to establish direct linkages between the influence of the econ- omy on cement consumption and its influence on construction and demolition activities.

The estimates of the stock model assume that cement discards exit the economy completely at

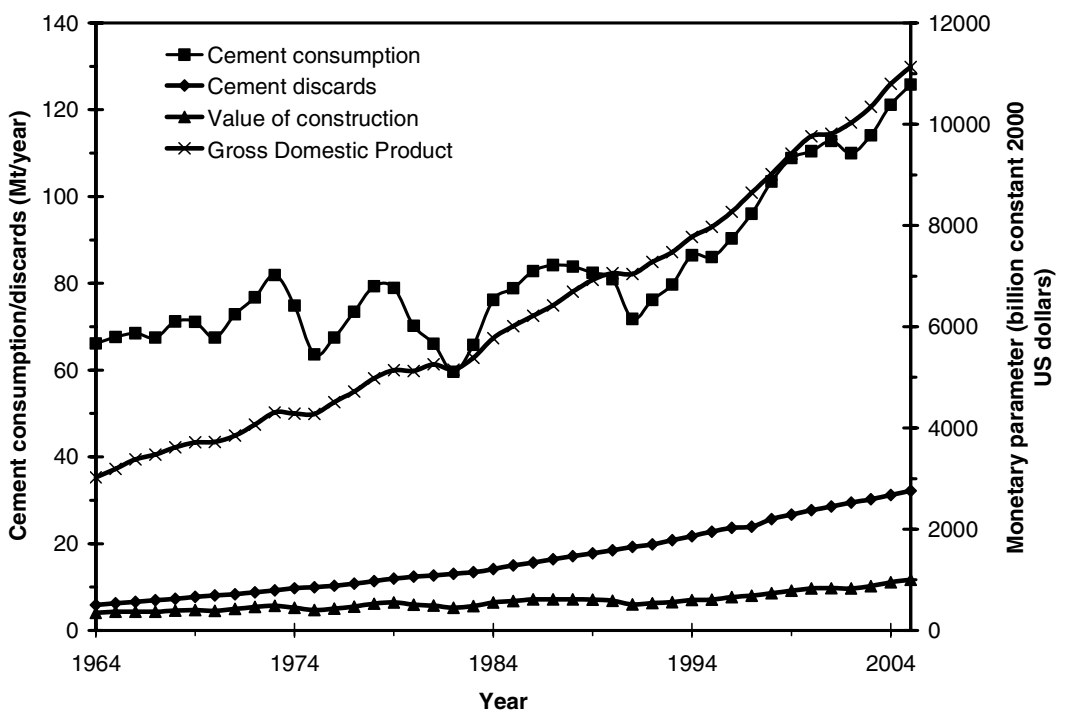

Figure 12 Trends in cement consumption, value of construction, gross domestic product, and cement discards in the United States from 1964 to 2005. Data source: USCB (2005c), van Oss and Kelly (2005), and World Bank (2005). 
end of life. At times, however, old structures are not completely demolished, and a part of the structure still remains in use, such as foundations for a concrete bridge (Van Oss 2006). In IE, the portion of the in-use stock of materials that has been put out of service but not discarded completely is referred to as "hibernating stocks" (Sörme et al. 2001; Kapur and Graedel 2004). In the United States, the number of abandoned housing units is on the rise, although reliable statistics on their number are scarce (Cohen 2001). According to a survey done by Miami University of Ohio and the University of South Carolina of over 100 cities in the United States, more than $18 \%$ of urban structures are unused (Interfire 2005). The Insurance Service Office has estimated that there are more than 21,000 "idle" properties over 15,000 square feet (approximately 1400 square meters) in the United States (Interfire 2005). The hibernating stocks of cement in the United States are not known or cannot be determined via the approach presented in this study. There is further need for empirical research in this regard to assess the influence of other explanatory variables, such as economy of the region or shift in demographics, that can cause obsolescence of civil infrastructure. If hibernating stocks can be determined, then those estimates should be subtracted from the results of this study to derive the true cement discards.

The input-flow distribution for cement comprises two subflows: apparent consumption of cement at the country level, and the fraction of apparent consumption utilized for each enduse category. The historical time-series data on apparent consumption of cement are well documented and reported annually by both the USGS and the Portland Cement Association (PCA). These apparent consumption data are not divided into different end uses, however. We bridged this data gap by assuming that cement end-use fractions do not change radically over several decades, as decadal changes by a few percentage points for each end-use fraction would not influence the results appreciably.

There is a lack of literature that has quantified the uncertainties associated with lifetime data for infrastructure uses. Therefore, for this study to address the uncertainty associated with lifetime distribution, a wide range of values were taken for the 50th and 90th percentile of the cumulative probability distribution function. The results represent the sensitivity of the lifetime distribution to estimates of in-use cement stocks.

\section{Conclusions}

A dynamic substance flow model has been developed to characterize the stocks and flows of cement mobilized and utilized during the 20th century in the United States. The model estimates the stock accumulation of cement as a function of cement consumption inflows into the economy, the distribution of cement end uses, and three lifetime distributions for each of the end uses. The model-derived estimate of the inuse cement stocks in the United States is in the range of 4.2 to $4.4 \mathrm{Gt}$. This indicates that $82 \%$ to $87 \%$ of cement utilized during the last century is still in use. On a per capita basis, this is equivalent to 14.7 tonnes of in-use cement stock per person, as compared to 6.0 tonnes per capita in 1950. The rate of growth of in-use cement stock has slowed. Streets and highways account for the largest proportion of cement discards.

The results of the dynamic model can plausibly act as a catalyst to stimulate further debate and the need for policy initiatives. The retirement of in-use stock of cement at its end of life would offer enormous environmental and resource management challenges, as it would lead to demand for more "new" cement. This study provides the first approximation of cement in-use stock in the United States. These stocks will exit the economy over the next few decades, providing immense opportunities for the construction and demolition debris industry. Presently, there is limited knowledge about generation of construction and demolition (C\&D) debris and the degree to which it is recovered and reused. The results of this study will provide baseline estimates for future discards and, hence, serve as a catalyst for policy and planning efforts by regulatory agencies, departments of transportation, and industry to put appropriate systems in place that will promote enhanced recycling of C\&D debris. The results will also help ensure an effective process of data collection and reporting to track to achieve the objective of not losing valuable resources to the environment in the form of $C \& D$ debris. 
The results of the study can also be used to determine how the extent of absorption of carbon dioxide by the built infrastructure over its lifetime can influence the carbon footprint of the complete life cycle of cement. There have been a number of studies that have analyzed cement-based infrastructure systems as carbon sinks (Gajda and Miller 2000; Pade and Guimaraes 2007) and empirically determined the carbon dioxide absorption or carbonation rates. The estimates of in-use stocks for different infrastructure systems can serve as inputs for climate change experts in the form of plausible carbon sinks that can continue absorb $\mathrm{CO}_{2}$ over their lifetime.

The retirement of the old stocks of cement will influence the cement and construction industry as well. The ratio of contemporary cement discards to cement consumption is approximately 1:4. The cement discards, on average, have been growing at $4 \%$ over the last 25 years, almost twice as fast as the growth in cement consumption. If the lifetime distribution can be determined more precisely through empirical studies, the stock and flow model could be refined and used to make better forecasts of cement demand. Presently, the forecasts are based on the likely trends in the economy and new construction projects and do not include old-stock replacement as a variable. The cement production capacity in the United States cannot meet the present demand. In addition, the rapidly growing economies of Asia are fueling regional shortages of cement in the United States and affecting construction activities as a result (Portland Cement Association 2004; van Der Schans 2005). Given the environmental and energy implications of the cement industry, the increased demand for cement will raise questions of trade-off between increasing domestic capacity and import reliance.

The probability of failure approach presented in this study can be applied to other material and product systems. This approach derives its origin from the field of reliability analysis, where reliability of a product is measured in terms of its probability of failure after a certain specified time period. The potential users of this approach should note that it assumes that when the product system fails, it is no longer considered as in-use stock. Certain product systems, however, go into hiber- nation after failure, as consumers do not discard them and potentially some of them come back into use with an additional service life after appropriate repair and maintenance measures. The estimation of in-use stock of such product systems cannot be determined with the presented approach.

The sustainability challenge of infrastructure systems is complex and multidimensional. This study takes the first step in addressing the challenge in the United States by analyzing how much cement we have used over the last century, how much is still in use, and how much of the discards were lost to the environment. Going forward, there is a need to catalyze our thinking and the need for action to limit our resource extraction and increase our capability to reduce the loss of valuable resources to the environment.

\section{Acknowledgements}

This research was funded through National Science Foundation MUSES (Material Use: Science, Engineering, and Society) Biocomplexity Program grants (Nos. CMS-0223971 and CMS0329416). The authors would also like to thank Hendrik G. van Oss of the U.S. Geological Survey for his help on technical information and data for this study, Melinda Tomaino Flores of Associated General Contractors of America for sharing data on recycling of construction and demolition debris, and all those who participated in the expert opinion survey as part of this research. The authors would like to thank Dr. Ananda Sen, Bonnie Motyka, and Akrain Phaibul at the Center for Statistical Consultation and Research for their help on statistical analysis. A version of this article is forthcoming in the book Changing Stocks, Flows and Behaviors in Industrial Ecosystems (Edward Elgar Publishing).

\section{Notes}

1. The amount of material contained in a reservoir is the stock (Graedel et al. 2002). A reservoir is a compartment or group of like compartments that contains the material of interest (Graedel et al. 2002).

2. One metric ton (tonne, $\mathrm{t})=10^{3}$ kilograms $(\mathrm{kg}$, $\mathrm{SI}) \approx 1.102$ short tons. 
3. One megajoule $(\mathrm{MJ})=10^{6}$ joules $(\mathrm{J}, \mathrm{SI}) \approx 239$ kilocalories $(\mathrm{kcal}) \approx 948$ British Thermal Units (BTU). One kilogram $(\mathrm{kg}, \mathrm{SI}) \approx 2.204$ pounds (lb).

4. Apparent consumption of a commodity is defined as the sum total of domestic production, net exports, and change in stocks.

5. http://www.blackwellpublishing.com/jie.

6. The distribution of individuals among different age groups in a population is defined as the age distribution, whereas the distribution of individuals who survive or live till a particular age is defined as the lifetime distribution.

7. End-of-life concrete discards are usually crushed and used as a fill material. This type of recycling of materials, whereby the material is recycled into a material of inferior value, is known as downcycling.

\section{References}

Alsop, P. A., H. Chen, A. L. Chin-Fatt, A. J. Jackura, M. I. McCabe, and H. H. Tseng. 2005. Cement plant operations handbook for dry process plants. Surrey, UK: Tradeship Publications.

ASCE (American Society of Civil Engineers). 2001. Renewing America's infrastructure: A citizen's guide. Washington, DC: ASCE.

ASCE. 2005. Report card for America's infrastructure. http://www.asce.org/reportcard/2005/index.cfm. Accessed April 2005.

Baccini, P. and P. H. Brunner. 1991. Metabolism of the anthroposphere. Berlin: Springer-Verlag.

BEA (Bureau of Economic Analysis). 2003. Fixed assets and consumer durables in the United States, 192597. Washington, DC: BEA.

BGS (British Geological Survey). 2004. Cement raw materials. Keyworth, UK: BGS.

Bolen, W. P. 2001. Sand and gravel, construction-2001. United States Geological Survey minerals yearbook 2001. Washington, DC: United States Geological Survey.

Bratteb $\varnothing$, H., H. Bergsdad, R. Bohne, and D. Müller. 2005. IE tools for built environment: Part I. MFA dynamics of the Norwegian dwelling stocks. http://www.indecol.ntnu.no/indecolwebnew/ publications/newsletter/webnews/documents/ brattebo_etal_stockholm.pdf. Accessed March 2006.

BTS (Bureau of Transportation Statistics). 2005. Highway performance monitoring system-core data. http://www.bts.gov. Accessed April 2005.

Cohen, J. R. 2001. Abandoned housing: Exploring lessons from Baltimore. Housing Policy Debate 12(3): 415-448.
DiPietro, G. 2004. Personal communication with G. DiPietro, Municipal Waste Reduction Branch, Municipal and Industrial Solid Waste Division, Washington, DC, 18 November 2004.

Duda, W. H. 1995. Cement data book. Third edition, Vol. 1. Weisbaden, Germany: French and European Publications.

Elshkaki, A., E. van der Voet, V. Timmermans, and M. Van Holderbeke. 2005. Dynamic stock modelling: A method for the identification and estimation of future waste streams and emissions based on past production and product stock characteristics. Energy 30(8): 1353-1363.

Flores, M. T. 2004. Personal communication with M. T. Flores, LEED ${ }^{\circledR} 2.0$ Accredited Professional, Environmental Program Coordinator, The Associated General Contractors of America, Alexandria, VA, 15 December 2004.

Gajda J. and F. MacGregor Miller. 2000. Concrete as a sink for atmospheric carbon dioxide: A literature review and estimation of $\mathrm{CO}_{2}$ absorption by Portland Cement concrete. Skokie, IL: Portland Cement Association

Graedel, T. E. and R. Klee. 2002. Getting serious about sustainability. Environmental Science and Technology 36(4): 526-529.

Graedel, T. E., M. Bertram, K. Fuse, R. B. Gordon, R. Lifset, H. Rechberger, and S. Spatari. 2002. The contemporary European copper cycle: The characterization of technological copper cycles. Ecological Economics 42(1-2): 9-26.

Graedel, T. E., D. van Beers, M. Bertram, K. Fuse, R. B. Gordon, A. Gritsinin A. Kapur, R. J. Klee, R. J. Lifset, L. Memon, H. Rechberger, S. Spatari, and D. Vexler. 2004. Multilevel cycle of anthropogenic copper. Environmental Science and Technology 38(4): 1242-1252.

Graedel, T. E., D. van Beers, M. Bertram, K. Fuse, R. B. Gordon, A. Gritsinin, E. M. Harper, A. Kapur, R. J. Klee, R. Lifset, L. Memon, and S. Spatari. 2005. The multilevel cycle of anthropogenic zinc. Journal of Industrial Ecology 9(3): 67-90.

Guinée, J. B., J. C. J. M. van der Bergh, J. Boelens, P. J. Fraanje, G. Huppes, P. P. A. A. H. Kandelaars, T. M. Lexmond, S. W. Moolenaar, A. A. Olsthoorn, H. A. Udo de Haes, E. Verkuijlen, and E. van der Voet. 1999. Evaluation of risks of metal flows and accumulation in economy and environment. Ecological Economics 30(1): 47-65.

Harrington, K. J. 2004. Personal communication with K. J. Harrington, FHWA Asphalt Pavement Engineer, HIPT, US Department of Transportation, Washington, D.C., 26 November 2004.

Hekkert, M. P., L. A. J. Joosten, and E. Worrell.2000. Analysis of the paper and wood flow in the 
Netherlands. Resources, Conservation and Recycling 30(1): 29-48.

Horvath, A. 2004. Construction materials and the environment. Annual Review of Environment and Resources 29: 181-204.

Interfire. 2005. IAAI/USFA vacant and abandoned buildings community group presentation outline. http://www.interfire.org/features/community_ talk.asp. Accessed April 2005.

JCHS (Joint Center for Housing Studies). 2001. Remodeling homes for changing households. Cambridge, MA: JCHS.

Joosten, L. A. J., M. P. Hekkert, and E. Worrell. 2000. Assessment of the plastic flows in the Netherlands using STREAMS. Resources, Conservation and Recycling 30(2): 135-161.

Kapur, A. and T. E. Graedel. 2004. Copper mines above and below the ground. Environmental Science and Technology 40(10): 3135-3141.

Kelly, T. 1998. Crushed cement concrete substitution for construction aggregates-A material flow analysis. U.S. Geological Survey Circular 1177. Washington, DC: U.S. Geological Survey.

Kleijn, R., R. Huele, and E. van der Voet. 2000. Dynamic substance flow analysis: The delaying mechanism of stocks, with the case of PVC in Sweden. Ecological Economics 32(2): 241254.

Komastu, Y., Y. Kato, T. Yoshida, and T. Yashiro. 1992. Report of an investigation of the lifetime distribution of Japanese houses at 1987. Journal of Architecture, Planning, and Environmental Engineering/Transactions of Architectural Institute of Japan 439: 101-110.

Melo, M. T. 1999. Statistical analysis of metal scrap generation: The case of aluminum in Germany. Resources, Conservation and Recycling 26(2): 91113.

Michaelis, P. and T. Jackson. 2000a. Material and energy flow through the UK iron and steel sector Part 1: 1954-1994. Resources, Conservation and Recycling 29(1-2): 131-156.

Michaelis, P. and T. Jackson. 2000b. Material and energy flow through the UK iron and steel sector Part 2: 1994-2019. Resources, Conservation and Recycling 29(3): 209-230.

Müller, D. B. 2006. Stock dynamics for forecasting material flows-Case study for housing in the Netherlands. Ecological Economics 56(1): 142156.

Nowak, A. S. and K. R. Collins. 2000. Reliability of structures. First edition. New York: McGraw-Hill Science/Engineering/Math.

OECD (Organization for Economic Cooperation and Development). 2001. Measuring capital: OECD manual. Measurement of capital stocks, consumption of fixed capital and capital services. Paris: OECD.

Pade, C. and M. Guimaraes. 2007. The $\mathrm{CO}_{2}$ uptake of concrete in a 100 year perspective. Cement and Concrete Research 37(9): 1348-1356.

Palm, V. and C. Ostlund. 1996. Lead and zinc flows from the technosphere to biosphere in a city region. Science of the Total Environment 192(1): 95109.

Patel, M. K., E. Jochem, P. Radgen, and E. Worrell. 1998. Plastic streams in Germany-an analysis of production, consumption and waste generation. Resources, Conservation and Recycling 24(34): 191-125.

Portland Cement Association. 2004. Cement shortage assessment. PCA Monitor.

Portland Cement Association. 2005. http://www. cement.org/Cement\%20Shortage\%20Flash\% 20Rpt.pdf. Accessed October 2004.

Schrank, D. and T. Lomax. 2004. The 2004 urban mobility report. Texas Transportation Institute, Texas A\&M University System, http://mobility. tamu.edu. Accessed April 2005.

Sörme, L., B. Bergbäck, and U. Lohm. 2001. Century perspective of heavy metal use in urban areas. Water, Air, and Soil Pollution Focus 1(3-4): 197211.

Spatari, S., M. Bertram, K. Fuse, T. E. Graedel, and H. Rechberger. 2002. The contemporary European copper cycle: One-year stocks and flows. Ecological Economics 42(1-2): 27-42.

Spatari, S., M. Bertram, R. B. Gordon, K. Henderson, and T. E. Graedel. 2005. Twentieth century copper flows in North America: A dynamic analysis. Ecological Economics 54(1): 37-51.

Tepordei, V. V. 2001. Crushed stone-2001. United States Geological Survey Minerals Yearbook 2001. Washington, DC: U.S. Geological Survey.

Turley, W. 2004. Personal communication with W. Turley, Executive Director, Construction Materials Recycling Association, Assoc. Publisher, Construction \& Demolition Recycling, Eola, IL, 17 November 2004.

USCB (U.S. Census Bureau). 2005a. Estimates of housing units. http://www.census.gov/popest/ housing/. Accessed April 2005.

USCB. 2005b. Population estimates. http://www. census.gov/popest/archives/1990s/. Accessed May 2005.

USCB. 2005c. Construction value put in place. http:// www.census.gov/const/www/totpage.html. Accessed May 2005.

USDOT (U.S. Department of Transportation). 2002. Status of nation's highways, bridges, and transit. Washington, DC: USDOT. 
USEPA (U.S. Environmental Protection Agency). 1998. Characterization of building-related construction and demolition debris in United States. Washington, DC: USEPA.

USGS (U.S. Geological Survey). 2003. Crushed stone-2003. United States Geological Survey Minerals Yearbook 2003. Washington, DC: USGS.

Van der Schans, P. W. 2005. Increasing material prices gouge construction industry. Construction Executive January 2005: 26-29.

Van Noortwijk, J. M. and H. E. Klatter. 2004. The use of lifetime distributions in bridge maintenance and replacement modeling. Computers and Structures 82: 1091-1099.

Van Oss, H. G. 2006. Personal communication with H. G. van Oss, Cement Commodity Specialist at US Geological Survey, Reston, VA, 14 September 2006.

Van Oss, H. G. and T. Kelly. 2005. Cement statistics: table on U.S. Geological Survey Cement Commodity webpage. http://minerals.usgs.gov/ minerals/pubs/of01-006/cement.xls. Accessed March 2006.

Van Oss, H. G. and A. C. Padovani. 2002. Cement manufacture and the environment, Part I: Chemistry and technology. Journal of Industrial Ecology 6(1): 89-105.

Van Oss, H. G. and A. C. Padovani. 2003. Cement manufacture and the environment, Part II: Environmental challenges and opportunities. Journal of Industrial Ecology 7(1): 93-126.
Wagner, L. A. 2002. Materials in the economy-material flows, scarcity and the environment. U.S. Geological Survey Circular 1221. Washington, DC: U.S. Geological Survey.

World Bank. 2005. World development indicators. http://devdata.worldbank.org/dataonline/. Accessed May 2005.

Zeltner, C. B., H. P. Bader, R. Scheidegger, and P. Baccini. 1999. Sustainable metal management exemplified by copper in the USA. Regional Environmental Change 1(1): 31-46.

\section{About the Authors}

Amit Kapur is a consultant with PE Americas in Boston, Massachusetts. He was a postdoctoral fellow at the Center for Sustainable Systems at the School of Natural Resources and Environment, University of Michigan, in Ann Arbor, Michigan, when this study was conducted. Gregory Keoleian is an associate professor and codirector at the Center for Sustainable Systems at the University of Michigan. Alissa Kendall is an assistant professor at the Department of Civil and Environmental Engineering, University of California at Davis. Stephen E. Kesler is a professor in the Department of Geological Sciences, University of Michigan.

\section{Supplementary Material}

The following supplementary material is available for this article:

Figure S1. Generic cement life cycle.

Figure S2. Age distribution of in-use bridges in the United States (ca. 2004) . (Data source: FHWA 2004).

Figure S3. Age distribution of in-use housing units in the United States (ca. 2003) . (Data source: USDHS 2004).

Table S1. Contemporary nonfuel raw material consumption for the manufacture of cement and clinker in United States, 1995-2000.

This material is available as part of the online article from:

http://www.blackwellpublishing.com/doi/abs/10.1111/j.1530-9290.2008.00055.x

(This link will take you to the article abstract).

Please note: Blackwell Publishing is not responsible for the content or functionality of any supplementary materials supplied by the authors. Any queries (other than missing material) should be directed to the corresponding author for the article. 